\title{
Design of learning modules writing factual text based on discovery learning by using mobile devices
}

\author{
S Ramadhan ${ }^{1}$, Y Asri², E Sukma ${ }^{3}$, V Indriyani ${ }^{4}$ \\ \{syahrul_r@fbs.unp.ac.id\} \\ 1,2,3,4 Universitas Negeri Padang, Jl. Prof Dr. Hamka Air Tawar, Padang, Indonesia
}

\begin{abstract}
Innovation and development of language teaching materials that are appropriate to the development of science and technology need to be done. At present, the development of knowledge and technology has an impact on changing generations. The use of technological devices, such as digital media, mobile applications, websites, etc., has resulted in a change in needs that allows all activities to move faster, one of which is information and knowledge. That has a big impact on education. One teaching material that can be developed is a learning module. At this time, the learning module developed can be done using a variety of digital devices, one of which is mobile. By using a mobile device, practical learning modules are used and can be equipped with various media. The module developed is a learning module writing factual text on the basis of Discovery Learning. This research is R \& D (research \& development) using a 4$\mathrm{D}$ model (define, design, develop, and dessiminate). Based on the results of validation and trials it was concluded that the learning module is valid, practical, and effective in learning Indonesian.
\end{abstract}

Keywords : Development, Learning, Mobile

\section{Introduction}

Writing is a challenging task for language students. Students have problems in fulfilling the writing requirements because of their low language skills [1]. Writing requires various sub-skills and can also be considered as the most difficult linguistic skills to develop because it is a versatile and complex skill [2]. The writing process requires a series of mental processes before physical action [3]. In addition to linguistic competence, the compotency that must be mastered in writing skills includes cognitive, social, and cultural competencies [4][5][6].

Various difficulties can be found by students in writing learning. Students must learn different writing genres, which include expository, descriptive, reflective, narrative, factual, argumentative, and so on that are demanded in the language curriculum [1]. Another difficulty stems from the fact that students need various skills and knowledge when writing. One type of text that students learn in language learning at the high school level is factual text. In general, texts can be divided into two types, namely literary texts and factual texts [7]. Factual text consists of repeated story texts, responses, explanations, discussions, information reports, expositions and procedures [8]. Based on this, one alternative is to develop appropriate teaching materials to be able to help students in writing learning. The selection of the development of teaching materials to address students 'problems in writing skills is because teaching materials are one of the important components that influence students' creativity in writing learning [9]. In addition, teaching materials are easy to understand, practical, fun, 
equipped with clear instructions, containing a complete description of the material, accompanied by examples and exercises [10]. Teaching materials also contribute to the success of learning and help the class become more enjoyable, better time management and increase the level of productivity in the classroom [11].

One teaching material that can be developed or used by teachers is a learning module that can be developed by loading learning models that are in accordance with the text being studied [12]. The learning model that can be used is the Discovery Learning model. Models in which students are permitted to discover new rules and new ideas, not memorize what is said or conveyed by the teacher [13] [19]. Students are directly involved in learning problems, to find answers through searching and finding problems [15]. When students take part in an investigation, they get pleasure and satisfaction that complement each other with what they do, feel, and share, and what and how others do and feel during the discovery process [16].

Discovery Learning is chosen as an innovation in developing teaching materials because this model can improve material mastery, retention, and more significant transfer of knowledge [16][17]. In addition, this model can improve critical thinking skills [18], improve reasoning, mastery of concepts [19][20], and can help students in language learning, especially to improve skills writing students. The advantages of this model are that students can play an active role in student-centered learning activities, but the disadvantage is that if students cannot gather a variety of information at the beginning of the Discovery Learning activity process then the learning process cannot continue well. Therefore, learning can be done using one mobile device or termed Mobile Learning. Mobile Learning can be defined as a type of learning where mobile devices, such as cellphones, smart phones, and tablets are used as teaching and learning tools [21]. Revolution in the field of information and communication technology has led to many settings where students can gain knowledge [22]. The integration of mobile phones for learning has become well-known and widely adopted in many language teaching schools [23]. However, due to the high cost of mobile devices, networks, low network transmission rates, and limited educational resources, mobilelearning is not widely used [24]. However, in the 21st century, there has been an increase in mobile device sales, rapid advances in mobile technology and features and increased availability of various mobile applications that allow students to have the opportunity to carry out learning activities using mobile devices [25]. Today, mobile devices allow users to call, text, email, video conferencing, micro blogs, interact on social networks, surf the Internet, watch and share videos and images, play video games and utilize a variety of software-driven applications [26].

The use of mobile device technology for learning has the ability to influence teacher experience and student academic achievement [27]. Most of these mobile devices contribute greatly to student literacy skills, information and communication technology skills [28] and easy accessibility of information such as accessing learning materials, sending learning material to students, and communicating with other students [21]. Pedagogical processes can also be carried out in full or in part, thereby increasing lifelong learning both in formal and informal education settings [29]. Based on this explanation, the purpose of this study is to describe the design of learning modules in writing factual text based on discovery learning by using mobile devices.

\section{Method}


The type of research used in this study is research and devolopment. This study aims to produce certain products. The results of this study are in the form of learning modules based on Discovery Learning text writing with mobile devices. The module development process is carried out following the 4-D model suggested by Thiagarajan, et. al. which consists of four stages of development, namely define, design, develop, and disseminate. The types of data in this study are quantitative data and qualitative data. In this paper, the results of the study will be discussed in this section are the design of the learning module, the validity of the product, and the percentage of student learning activities using the module.

\section{Result and Disscusion}

Many experts discuss about Discovery Learning with diverse learning steps. Veermans shows five Discovery Learning processes including orientation, hypothesis generation, hypothesis testing, conclusions, regulatory processes [30].Next, Hanafi states that the stages in Discovery consist of six parts, namely stimulation, problem statement, data collection, data processing, verification and generalization [31]. Based on the school curriculum in Indonesia, learning steps with Discovery Learning include stimulation, problem identification, data collection, data processing, verification, and drawing conclusions [32][33]. There are five steps in implementing learning with Discovery Learning, including formulation of problems, setting temporary answers, searching for information (data and facts) to answer temporary questions, drawing conclusions and applying conclusions [34]. Based on several syntax or stages of implementing learning with Discovery Learning, the design of learning used in the development of learning modules designed in this study is described as follows.

First, learning stimulation. This stage has the opportunity to provide intensive guidance or minimal guidance to students for example, manual guidance, simulations, feedback, or examples of problems. The extent to which students are given assistance depends on the difficulty in finding target information with less help. Information must be found by students within the boundaries of the task and the material. Students have more responsibility in learning concepts [35]. In essence, students build their ideas about domains, concepts, examples and learning environments regarding learning that is carried out [30], so students learn to understand the rules and mechanisms underlying the concept [13] and can find concepts independently [36].

Second, problem identification. This stage involves students to find out about the problems they have learned and the experiences they have. This allows students to play an active role in the learning process by answering and solving problems to find concepts that are durable and easy to remember. Based on the identification carried out by students at this stage can encourage students to ask questions and formulate their own tentative answers, and to conclude general principles from examples or practical experience. In essence, students participate in making many decisions about what, how, and when something must be learned and even play a major role in making such decisions [31].

Third, gather information. Instead of being 'told' content by the teacher, it is expected that students must look for examples and 'find principles or concepts that must be learned [31]. At this stage it allows students the opportunity to experiment and find something for themselves; foster curiosity reason to record their procedures and findings [37]. It can provide benefits for students to be able to use and apply knowledge with facilities in solving problems when the information they learn is obtained in an active and constructive way [13]. 
In the learning modules that are designed, this stage is at the core of the importance of using mobile devices. Although the module was developed by the application of mobile devices, mobile devices do not play an important role because their function is only as a substitute for print modules that turn electronic. Stages of collecting information on discovery learning require students to find information from various sources, so students can access several sites providing information to get material in writing learning activities. Information, data, and facts are an important part of writing factual texts. So that mobile devices can be used as an alternative to find this information. In the learning module, students can be directed to find information by asking questions about the text material and can attach several links from several sites providing information related to the text that will be written by students.

Fourth, processing information. This stage students take an active role in creating, integrating, and generalizing knowledge [38]. Finding yourself or solving problems they face will require students to develop creative ways of thinking. This is in accordance with one of the goals of discovery in learning, namely to develop creativity and critical thinking skills [15]. In addition, students are more active in learning activities, finding independently, building experience, mastering the concepts of material learned, improving elaborate thinking skills, solving problems to create, connect, and generalize knowledge; and activities to combine new knowledge and existing knowledge [39]. In the learning module designed, this stage is an important point in learning writing. Writing requires various sub-skills such as linguistic competence, cognitive, social, and cultural competencies [4][5][6].

Fifth, conclude. Directing students to find their own principles or concepts that were previously unknown, has been proven to improve students' skills in listening to language learning [31]. In the learning module designed, this stage is the last stage in discovery learning activities. After students write factual text, students can conclude the concept of learning based on the learning activities that have been carried out. These conclusions can be in the form of material, concepts, or the value of the learning activities.

The design of the learning module that has been developed was previously validated by experts. The results of the validation can be seen in table 1 and learning activities and presentation of student learning activities can be seen in table 1.

Table 1. Learning module validation result by experts

\begin{tabular}{|c|c|c|c|c|}
\hline No. & Rated aspect & Indicator & Validity (\%) & Category \\
\hline 1. & $\begin{array}{l}\text { Feasibility of } \\
\text { content }\end{array}$ & $\begin{array}{l}\text { Accuracy of module content with curriculum } \\
\text { Material or concept } \\
\text { Content }\end{array}$ & 93,75 & Very valid \\
\hline 2. & Linguistics & $\begin{array}{l}\text { Linguistics } \\
\text { Submission ideas and styles }\end{array}$ & 96,87 & Very valid \\
\hline 3. & Presentation & $\begin{array}{l}\text { Submission of Core and Basic Competencies, } \\
\text { Indicators and Learning Objectives } \\
\text { Material presentation } \\
\text { Presentation of learning modules }\end{array}$ & 92,50 & Very valid \\
\hline 4. & Desain & $\begin{array}{l}\text { Display of learning modules } \\
\text { Use of images, letters, colors, etc. }\end{array}$ & 85,71 & Very valid \\
\hline \multicolumn{3}{|c|}{ Validation of Learning Modules by Overall Experts } & 92,20 & Very valid \\
\hline
\end{tabular}


Table 2. Design Of Learning Modules Learning Factual Text Based on Discovery Learning by Using Mobile Devices and Percentage of Student Activities

\begin{tabular}{|c|c|c|c|}
\hline $\begin{array}{l}\text { Coure } \\
\text { name }\end{array}$ & \multicolumn{3}{|c|}{ Writing factual text } \\
\hline Text & \multicolumn{3}{|c|}{ Explanatory texts and procedural texts } \\
\hline Objectives & \multicolumn{3}{|c|}{$\begin{array}{l}\text { Students understand the structure, and linguistic factual texts that are learned. } \\
\text { Students are skilled in writing factual text texts according to the structure and } \\
\text { language of the text. } \\
\text { Students are skilled at utilizing mobile devices to find various information from } \\
\text { various learning media. }\end{array}$} \\
\hline $\begin{array}{l}\text { Teaching } \\
\text { Model }\end{array}$ & \multicolumn{3}{|c|}{ Discovery learning and mobile learning } \\
\hline Syntax & \multicolumn{2}{|r|}{ Learning Activities Using Modules } & $\begin{array}{l}\text { Student Activities } \\
\qquad(\%)\end{array}$ \\
\hline 1. & $\begin{array}{l}\text { Learning } \\
\text { Stimulation }\end{array}$ & $\begin{array}{l}\text { Showing examples, concept maps, serial } \\
\text { images, cycles, or videos, and students answer } \\
\text { questions about stimulation and illustrations } \\
\text { that are displayed about the concept of learning. }\end{array}$ & $96,7 \%$ \\
\hline 2. & $\begin{array}{l}\text { Problem } \\
\text { Identification }\end{array}$ & $\begin{array}{l}\text { Identify information based on the stimulation } \\
\text { displayed. }\end{array}$ & $86,7 \%$ \\
\hline 3. & $\begin{array}{l}\text { Gather } \\
\text { Information }\end{array}$ & $\begin{array}{l}\text { Information, data, and facts that can be } \\
\text { collected through various media found on } \\
\text { mobile devices. In the learning module can } \\
\text { display links so students are more directed. }\end{array}$ & $85,0 \%$ \\
\hline 4. & $\begin{array}{l}\text { Processing } \\
\text { Information }\end{array}$ & $\begin{array}{l}\text { The writing process needs to be done at this } \\
\text { stage such as inventorying that has been done, } \\
\text { determining the theme of the activity, } \\
\text { compiling the framework, collecting materials, } \\
\text { and developing the framework. From the series } \\
\text { of activities students write text based on } \\
\text { information that has been collected from } \\
\text { various sources. }\end{array}$ & $76,7 \%$ \\
\hline 5. & Conclude & $\begin{array}{l}\text { Students can deduce concepts from learning } \\
\text { based on the learning activities that have been } \\
\text { carried out. These conclusions can be in the } \\
\text { form of material, concepts, or the value of the } \\
\text { learning activities. }\end{array}$ & $83,3 \%$ \\
\hline
\end{tabular}

Student learning activities are observation data by assessing the presentation of students who take part in the activity according to the instruction of the learning module designed. The overall percentage results show that students are very active in the learning process by using modules according to the syntax designed. This is evidenced by the percentage value $>80 \%$.

\section{Conclusions}


Based on the analysis it was found that using various teaching materials can be used as an alternative for the language learning process, especially writing learning. The difficulty found in writing learning stems from the fact that students need various skills and knowledge when writing. For example, topics, text functions, prospective readers, content, organization, mechanics, adequate vocabulary inventory, grammar knowledge, and other discourse strategies for organizing text. To overcome this, can use teaching materials by integrating learning models that are in accordance with the text being studied, one of which is learning modules writing factual texts based on Discovery Learning. The learning module used has limited information. Even though writing learning requires a lot of material so students can write a text. One alternative that can be done by innovating is using Mobile Learning, which is learning using various mobile devices. Through the use of mobile devices, especially various applications that can be accessed both online and offline, can help teachers and students find the various information needed to write.

\section{Acknowledgments}

Thank you to Universitas Negeri Padang for permitting the research.

\section{References}

[1] Q Yusuf, Z Jusoh and Y Q Yusuf 2019 International Journal of Instruction 121399

[2] C Espin, J W Weissenburger and B J Benson 2004 Exceptionality 1255

[3] İ S Aydın 2019 Journal of Education and Training Studies 7180

[4] K di Gennaro 2016 Assessing Writing 291

[5] J. G. Mallia 2017 Arab World English J 82

[6] S S Hussain 2018 Arab World English J 8208

[7] P Hall 2001 Writing and grammar: Communication in action (Trenton: Prentice-Hall, Inc)

[8] K. Anderson and M. Anderson 1997 Text Type in English 1 (South Yarra: Macmillan Education Australia PTY Ltd)

[9] H Andheska 2017 bahastra XXXVI 55

[10] H I Saglam 2011 Tojet 1036

[11] Atmazaki and V Indriyani 2019 Advances in Social Science, Education and Humanities Research 301235

[12] V Indriyani and S Ramadhan 2017 2nd Annual International Seminar on Transformative Education and Educational Leadership 201716

[13] J S Brunner 1961 Harv. Educ. Rev.31 25

[14] R E Mayer 2004 American psychologist 5914

[15] M H Rahman 2017 International Journal of Sosial Science \& Educational Studies 498

[16] A G Balım 2009 Eurasian Journal of Educational Research 353

[17] S H Jew 2012 Who are self-discovery learners online? A literature review (USA: Constructing Self-Discovery Learning Spaces Online)

[18] P Chen, A K Tolmie and H Wang 2016 International Journal of Educational Research 841

[19] C W.Keys and L A Bryan 2001 Journal of Research in Science Teaching: The Official Journal of the National Association for Research in Science Teaching 38631

[20] J D Novak 2002 Science education 86548

[21] Y Baek, H Zhang and S Yun 2017 Tojet 16154

[22] M L Wagner 2016 International Journal of Environmental and Science Education 118562

[23] O Suwantarathip and W Orawiwatnakul 2015 Tojet 14163 
[24] M Wang, Y Chen and M J Khan 2014 The International Review of Research in Open and Distributed Learning 15255

[25] C L Kee and Z Samsudin 2014 Tojet 13107

[26] A Lepp, J E Barkley and A C Karpinski 2014 Computers in Human Behavior 31343

[27] K Mac Callum and L Jeffrey Australas 2013 Australasian Journal of Educational Technology 29 303

[28] O J Odiakaosa, N Dlodlo and N Jere 2017 Online Submission 113

[29] G Vavoula and M Sharples 2009 International Journal of Mobile and Blended Learning 154

[30] H Lingyi 2010 Procedia-Social and Behavioral Sciences 24032

[31] Hanafi 2016 Dinamika Ilmu 16291

[32] A A Carin 1993 Teaching modern science (New York: Macmillan Publishing Company)

[33] Kemendikbud 2014 Konsep dan Implementasi Kurikulum 2013 (Jakarta: Kemendikbud)

[34] S Sagala 2003 Konsep dan makna pembelajaran (Bandung: Alfabeta)

[35] G Singaravelu 2012 Journal on English Language Teaching 257

[36] J Künsting, J Kempf and J Wirt 2013 Contemporary Educational Psychology 38349

[37] D Sofeny 2017 Jurnal Penelitian Humaniora 1841

[38] B A Anders 2012 Human motivations and discovery learning (USA: Constructing SelfDiscovery Learning Spaces Online)

[39] F Kristin 2016 Jurnal Pendidikan Dasar 290 